\title{
Correspondance d'Angleterre
}

Sur quelques publications parues en anglais sur la période révolutionnaire(années 1997-1999)

\section{Malcom Crook}

\section{(2) OpenEdition}

1 Journals

Édition électronique

URL : https://journals.openedition.org/ahrf/2274

DOI : $10.4000 /$ ahrf.2274

ISSN : 1952-403X

Éditeur :

Armand Colin, Société des études robespierristes

Édition imprimée

Date de publication : 1 mars 2000

Pagination : 141-145

ISSN : 0003-4436

\section{Référence électronique}

Malcom Crook, «Correspondance d'Angleterre », Annales historiques de la Révolution française [En ligne], 319 | janvier-mars 2000, mis en ligne le 11 mai 2006, consulté le 23 avril 2022. URL : http:// journals.openedition.org/ahrf/2274 ; DOI : https://doi.org/10.4000/ahrf.2274

Ce document a été généré automatiquement le 23 avril 2022.

Tous droits réservés 


\section{Correspondance d'Angleterre}

Sur quelques publications parues en anglais sur la période révolutionnaire(années 1997-1999)

\section{Malcom Crook}

Livres

1 Adcock Michael, Chester Emily et Whiteman Jeremy (eds), Revolution, society and the politics of memory, Proceedings of the Tenth George Rudé seminar on French history and civilisation, Melbourne, 1998.

2 Andress David, French society in revolution. 1789-1799, Manchester, Manchester University Press, 1999.

3 Blanning Tim, The French Revolution: Class war or culture clash?, Macmillan, London, 1998.

4 Carpenter Kirsty, Refugees of the French Revolution: émigrés in London. 1789-1802, Macmillan, London, 1999.

5 Carpenter Kirsty and Mansel Philip (eds), The french émigrés in Europe and the struggle against the Revolution. 1789-1814, London, Macmillan, 1999.

6 Cox Marvin (ed.), The place of the French Revolution in history: interpretations and perspectives, Boston, Houghton Mifflin, 1998.

7 Crook Malcolm, Napoleon comes to power. Democracy and dictatorship in revolutionary France, 1795-1804, Cardiff, University of Wales Press, 1998.

8 Gallaher John G., General Alexandre Dumas: soldier of the French Revolution, Carbondale, Southern Illinois University Press, 1997.

9 Gough Hugh, The Terror in the French Revolution, Macmillan, London, 1998.

10 Hampson Norman, The perfidy of Albion. French perceptions of England during the French Revolution, Macmillan, London, 1998.

11 Higonnet Patrice, Goodness beyond virtue. Jacobins during the French Revolution, Cambridge, Mass., Harvard University Press, 1998.

12 Huet Marie Hélène, Mourning glory: the will of the French Revolution, Philadelphia, University of Pennsylvania Press, 1997. 

1792-1804, Aldershot, Ashgate, 1998. murder in the Corbières, Oxford, Oxford University Press, 1999. Yale University Press, 1998. Princeton, Princeton University Press, 1998. revolution, Niwot, University Press of California, 1999. de doléances » of 1789, Stanford, Stanford University Press, 1998.

Articles 1791 », European History Quarterly, 28 (1998), pp.51-80. pp. 183-209. Commune ", The Historical Journal, 42 (1999), pp. 597-622. Historical Studies, 22 (1999), pp. 557-611. law in popular politics », Past and Present, 164 (1999), pp.81-121. Politics, 5 (1997), pp. 97-124. Canadian Journal of History, 32 (1997), pp. 339-346.

Macleod Emma V., A war of ideas: British attitudes to the wars anainst revolutionarv France

McPhee Peter, Revolution and environment in southern France. 1780-1830. Peasants, lords and

Morris Marilyn, The British monarchy and the French Revolution, New Haven and London,

Porterfield Todd, The allure of empire: art in the service of French imnerialism. 1798-1836,

Scott Samuel F., From Yorktown to Valmy: the transformation of the French army in an ane of

Shapiro Gilbert et Markoff John, Revolutionarv demands : a content analysis of the "cahiers

Andress David, « Press and public in the French Revolution : a Parisian case-study from

Andress David, "The denial of social conflict in the French Revolution: discourses around the Champ de Mars massacre, 17 July 1791 », French Historical Studies, 22 (1999),

Bailey Charles R., " Municipal government and secondary education during the early French Revolution : did decentralization work ? », French History, 12 (1998), pp. 25-42.

Brown Howard G., « From organic society to security state : the war on brigandage in France, 1797-1802 », Journal of Modern History, 69 (1997), pp.661-695.

Brown Howard G., «Domestic state violence : repression from the Croquants to the

Christofferson Michael, «An anti-totalitarian history of the French Revolution: François Furet's Penser la Révolution in the intellectual politics of the late 1970s ", French

Cole John R., "Debunking Roussel's "report" on the Society of Revolutionary Republican Women », French Historical Studies, 21 (1998), pp.181-191.

Desan Suzanne, «Reconstituting the social after the Terror: family, property and the

Desan Suzanne, "War between brothers and sisters": Inheritance law and gender politics in revolutionary France », French Historical Studies, 20 (1997), pp.597-634.

Dicaprio L., "Women, work and welfare in old regime and revolutionary Paris », Social

Doyle William, "Abolishing the sale of offices: Ambitions, ambiguities and myths",

Gemie Sharif, «France and the Val d'Aran : politics and nationhood on the Pyrenean border, c.1800-1825 », European History Quarterly, 28 (1998), pp. 311-345.

31 Gruder Vivian R., « Political news as coded messages : the Parisian and provincial press in the Pre-Revolution, 1787-1788 », French History, 12 (1998), pp.1-24. 

299-324. 375-392. 32 (1997), pp. 315-337. History, 12 (1998), pp. 127-148. Studies, 31 (1997-1998), pp. 175-197. (1997-1998), pp. 153-174. (1997), pp. 415-436. Journal, 41 (1998), pp. 225-258. of Political Thought, 18 (1997), pp. 64-103 et 267-325. (1998), pp. 371-383. Family History, 22 (1997), pp. 425-461. II », French Historical Studies, 20 (1997), pp.635-664.
Hanson Paul R., « Monarchist clubs and the pamphlet debate over political legitimacy in the early years of the French Revolution ", French Historical Studies, 21 (1998), pp.

Kennedy Emmet, « Taste and Revolution », Canadian Journal of History, 32 (1997), 37, pp.

Kwass Michael, «A kingdom of taxpayers : state formation, privilege and political culture in eigtheenth-century France », Journal of Modern History, 70 (1998), pp. 295-339.

Leith James, "The Terror : Adding the cultural dimension », Canadian Journal of History,

Livesey James, "Agrarian ideology and commercial republicanism in the French Revolution ", Past and Present, 157 (1997), pp. 94-121.

Luckett Thomas M., "Hunting for spies and whores: A Parisian riot on the eve of the French Revolution », Past and Present, 156 (1997), pp.116-143.

McLeod Jane, "Provincial book trade inpectors in eighteenth-century France », French

McMahon Darrin M., "The Counter-Enlightenment and the low life of literature in prerevolutionary France », Past and Present, 159 (1998), pp.77-112.

Mitchell J.E., «Picturing sisters : 1790 portraits by J.-L. David », Eighteenth-Century

Mirzoeff N., «Revolution, representation, equality: Gender, genre, and emulation in the Académie royale de peinture et sculpture, 1785-1793 », Eighteenth-Century Studies, 31

Rapley Elizabeth and Rapley Robert, "An image of religious women in the Ancien Régime: The État des Religieuses of 1790-1791 », French History, 11 (1997), pp. 387-410.

Roberts W., "The visual rhetoric of Jean-Louis Prieur », Canadian Journal of History, 32

Rosenband Leonard N., «Jean-Baptiste Réveillon : A man on the make in old regime France », French Historical Studies, 20 (1997), pp. 481-510.

Rowe Michael, «Between empire and home town: Napoleonic rule on the Rhine, 1799-1814 », The Historical Journal, 42 (1999), pp. 643-74.

Savage Gary, "Favier's heirs: The French Revolution and the secret du roi », Historical

Sonenscher Michael, "The nation's debt and the birth of the modern republic: The French fiscal deficit and the politics of the Revolution of 1789 (parts I and II) », History

Sonenscher Michael, «Enlightenment and Revolution », Journal of Modern History, 70

Spangnoli P.G., « The unique decline of mortality in revolutionary France », Journal of

Sullivan Charles R., "The first chair of political economy in France: Alexandre Vandermonde and the Principles of Sir James Steuart at the École Normale of the Year 

of Political Thought, 18 (1997), pp. 652-676.

Thèses Wisconsin, 1997. revolutionary France, PhD Thesis, University of Florida, 1998. economy after the Terror, PhD Thesis, Stanford University, 1997. University of Leeds, 1997. Jersey, 1997. Harvard University, 1997. in France, 1789-1830, PhD Thesis, University of Chicago, 1998. Oxford University, 1997. PhD Thesis, University of Oklahoma, 1998. University, 1997. 1777-1809, PhD Thesis, University of Pittsburgh, 1997. City University of New York, 1998.

Swann Julian, «Power and provincial politics in eighteenth-century France: The Varenne Affair, 1757-1783 ", French Historical Studies, 21 (1998), pp. 441-474.

Thomas P., « The revolutionary festival and Rousseau's quest for transparency », History

Beckstrand Lisa A., Olympe de Gouges and Manon Roland: constructions of feminine identity within the context of the French Revolution, PhD Thesis, University of

Bell Claire L., Citoyennes françaises: an integral analysis of women's activism in

Colman Daniel H., The foundation of the French liberal republic : politics, culture and

Elliott-Wright Philipp J., British officers and the French army, 1788-1815, PhD Thesis,

Glotzer Scott B., Napoleon, the Jews, and the construction of modern citizenship in early nineteenth century France, PhD Thesis, Rutgers, The State University of New

Goodheart Eric A., Adoption in the discourses of the French Revolution, PhD Thesis,

Heuer Jennifer, Foreigners, families and citizens : contradictions of national citizenship

McMahon Darrin M., Enemies of the Enlightenment : antiphilosophes and the birth of the French Far Right, 1778-1830, PhD Thesis, Yale University, 1998.

Michaelis Richard, The secular clergy of the Ille-et-Vilaine, 1789-1804, PhDThesis,

Naginski Erika, Sculpture and Revolution : the art of commemoration at the end of the Enlightenment, PhD Thesis, University of California, Berkeley, 1997.

Roussel Bridget A., A rhetorical analysis of the popular society addresses of Thermidor,

Sagraves Julia A., The field of honour: paintings, painters, and the politics of masculinity at the Salon during the First French Empire, PhD Thesis, Northwestern

Sepinwall Alyssa R., Regenerating France, regenerating the world: the abbé Grégoire and the French Revolution, 1750-1831, PhD Thesis, Stanford University, 1998.

Simon Jonathan, The alchemy of identity: pharmacy and the chemical revolution,

Trinkle Dennis, The Napoleonic press : coverage of private and public affairs from the Revolution to Waterloo, PhD Thesis, University of Cincinnati, 1998.

Turley Katherine M., Channels of influence : patronage, power and politics in Poitou from Louis XIV to the Revolution, PhD Thesis, University of California at Irvine, 1997.

Werner Paul, David's basket : art and activism in the French Revolution, PhD Thesis, 
70 Weinzierl John F., The military and political career of Claude-Victor Perrin, PhD Thesis, Florida State University, 1997.

71 Woell Edward J., Counterrevolutionary catholicism in western France : the battle of belief at Machecoul, 1774-1914, PhD Thesis, Marquette University, 1997.

\section{AUTEUR}

MALCOM CROOK

Keele University 